\title{
ECONOMICS FOR A CIVILIZED SOCIETY
}


Also by Paul Davidson

THEORIES OF AGGREGATE INCOME DISTRIBUTION

AGGREGATE SUPPLY AND DEMAND ANALYSIS

THE DEMAND AND SUPPLY OF OUTDOOR RECREATION

MILTON FRIEDMAN'S MONETARY FRAMEWORK

*MONEY AND THE REAL WORLD

*INTERNATIONAL MONEY AND THE REAL WORLD

* Also published by Palgrave Macmillan 


\section{Economics for a Civilized Society}

\section{Greg Davidson}

Astrophysics Program Analyst

National Aeronautics and Space Administration

\section{Paul Davidson}

J. Fred Holly Chair of Excellence in Political Economy University of Tennessee

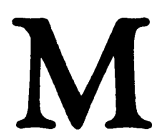


(C) Greg Davidson and Paul Davidson 1988

All rights reserved. No reproduction, copy or transmission of this publication may be made without written permission.

No paragraph of this publication may be reproduced, copied or transmitted save with written permission or in accordance with the provisions of the Copyright Act 1956 (as amended), or under the terms of any licence permitting limited copying issued by the Copyright Licensing Agency, 33-4 Alfred Place, London WC1E 7DP.

Any person who does any unauthorised act in relation to this publication may be liable to criminal prosecution and civil claims for damages.

First published 1988

Published by

THE MACMILLAN PRESS LTD

Houndmills, Basingstoke, Hampshire RG21 2XS

and London

Companies and representatives

throughout the world

Typeset by Wessex Typesetters

(Division of The Eastern Press Ltd)

Frome, Somerset

Davidson, Greg

Economics for a civilized society.

1. Economics

I. Title II. Davidson, Paul

$330.1 \quad$ HB171

ISBN 978-0-333-43929-6 ISBN 978-1-349-19244-1 (eBook)

DOI 10.1007/978-1-349-19244-1 
To Louise and Tamah, and the rest of our family;

Diane, Robert, Cindy, and Christopher 


\section{Contents}

Preface

1 In Pursuit of Civilization 1

2 The Political Economy of Civilization 29

3 What's Wrong with Economists? 52

4 Why Taxpayers Pay their Taxes 69

5 The Basic Problem of an Entrepreneurial System - 96 Unemployment

6 Unemployment Develops Because Money Doesn't Grow 117 on Trees

7 Controlling Inflation 134

8 Policy for a Civilized Global Economy - Whose 158 International Debt Crisis is it Anyway?

9 A Final Summing Up

Sources and References $\quad 201$

$\begin{array}{ll}\text { Index } & 205\end{array}$ 


\section{Preface}

How did we come to write Economics for a Civilized Society? In many ways we have been working on this book for years, in our learning, teaching and writings. In our careers as a Professor at Pennsylvania, Rutgers and Tennessee, and as a student at Swarthmore and Harvard, we have frequently seen the intellectual history of economic thought fall to waste as it is distorted to fit within the current conventional wisdom known as 'neoclassical economics'.

At one extreme of neoclassical economics is the intellectual despotism of a discipline which is more ideological than empirical. More commonly we have found intelligent and well-intentioned economists whose work is needlessly constrained and ruined by the weakness of these neoclassical conceptual foundations upon which they have built their analysis. Ours is not the cynical message that economists do not know anything - the problems we see come more from the things that economists 'know' that just are not so.

Our goal is to provide a civilized approach to the important economic policy issues that face modern societies. Unfortunately, conventional neoclassical economic thought cannot penetrate the operations of an enlightened society. Yet Western societies have invested a great deal of intellectual effort in developing the database and analytical tools of this conventional analytical analysis. Hence we have tried to salvage what can be used, if properly modified for a civilized setting, of the conventional wisdom.

We therefore provide a civilized analytical structure which can support work already done in neoclassical economics, when the latter is modified to integrate valid critiques of the conventional wisdom. In so doing we hope not only to improve our understanding of the orthodox approach, but also to probe the crucial interactions between the self-interest basis of neoclassical economics and the civic values to which the orthodox approach is blind.

An understanding of the boundaries of conventional analysis and how one can go beyond this restrictive barbaric approach is not merely of academic importance. Whether we like it or not, current economic theory has become the bedrock of our public policy decision-making process as well as the basis for our philosophy of society and its laws. Economic theory not only affects our bank accounts, but it also, in large part, determines how our society is fed 
and housed, and even how much we think our society can afford to defend ourselves against epidemics or enemies threatening the very viability of our population. Conventional economic theory does influence our views of right and wrong, and can thereby change the context of our lives. Our hope is to provide guidance towards a more civilized approach to all these issues.

We would like to thank the following people for their comments on aspects of this manuscript: John Kenneth Galbraith, Robert Reich, Martin Kessler, Fred Zimmerman, Stephen Benko, William Kushner, Alan Plumley, Ellen Freeberg, John Powell, and Ellie Prockop. Others who have helped us with their comments on earlier aspects of what became the basis of this book include Amatii Etzioni, James Verdier, George Brockway, Dotty Robyn, Marty Linsky, John Dunlop, Malcolm Salter, Steve Kelman, Richard Zeckhauser, David Elwood, Harvey Liebenstein, Shah Ashiqazziman, Peter Swiderski, Ken Sharpe, and Charles Gilbert. Not everyone mentioned above will agree with all of our findings but we appreciate the insights that their comments provided.

We would also like to express our appreciation to the late Sidney Weintraub who taught us, in separate economics courses almost thirty years apart, the importance of the statement of William Stanley Jevons that 'In matters of philosophy and science authority has been the great opponent of truth. A despotic calm is usually the triumph of error. In the republic of the sciences sedition and even anarchy are beneficial in the long run to the greatest happiness of the greatest number.' From Sidney Weintraub we learned much - but especially we learned that, although it is more pleasant and easy to agree than disagree, it is necessary to speak out against the fallacies which find their way into the conventional wisdom.

Finally, we wish to thank Louise and Tamah, whose contributions (editorial and other) would have earned them mention above, except that they also deserve special recognition for tolerating us as we frequently woke up at three in the morning to write down just one more idea'.

Washington, $D C$

Greg Davidson

Knoxville, Tennessee

Paul Davidson 